May 2019

\title{
Learning Preferences Instead of Learning Styles: A Case Study of Hospitality Management Students' Perceptions of How They Learn Best and Implications for Teaching and Learning
}

Cynthia S. Deale

East Carolina University, cindea56@yahoo.com

Follow this and additional works at: https://digitalcommons.georgiasouthern.edu/ij-sotl

\section{Recommended Citation}

Deale, Cynthia S. (2019) "Learning Preferences Instead of Learning Styles: A Case Study of Hospitality Management Students' Perceptions of How They Learn Best and Implications for Teaching and Learning," International Journal for the Scholarship of Teaching and Learning: Vol. 13: No. 2, Article 11.

Available at: https://doi.org/10.20429/ijsotl.2019.130211 


\title{
Learning Preferences Instead of Learning Styles: A Case Study of Hospitality Management Students' Perceptions of How They Learn Best and Implications for Teaching and Learning
}

\begin{abstract}
This Scholarship of Teaching and Learning (SoTL) study focused on understanding more about how hospitality and tourism students prefer to learn and considers the implications that these preferences have for teaching methods. The case is made that learning preferences matter even though critics indicate that there is no evidence for the use of learning styles. Perceptions of students' learning preferences were gathered from students in six face-to-face undergraduate hospitality and tourism classes at a university in the southeastern United States. In accordance with previous research, hospitality students in this sample tended to prefer active learning opportunities. Implications, suggestions for teaching and further research, and limitations are presented.
\end{abstract}

\section{Keywords}

learning, teaching, learning preferences, learning styles

Creative Commons License

(c) $($ ) $\odot$

This work is licensed under a Creative Commons Attribution-Noncommercial-No Derivative Works 4.0 License.

Cover Page Footnote

$\mathrm{n} / \mathrm{a}$ 


\title{
Learning Preferences Instead of Learning Styles: A Case Study of Hospitality Management Students' Perceptions of How They Learn Best and Implications for Teaching and Learning
}

\author{
Cynthia S. Deale \\ East Carolina University
}

Received II September 2018;Accepted 22 April 2019

\begin{abstract}
This study focused on understanding more about how hospitality and tourism students prefer to learn and considers the implications that these preferences have for teaching methods. The case is made that learning preferences matter even though critics indicate that there is no evidence for the use of learning styles. Perceptions of students' learning preferences were gathered from students in six face-to-face undergraduate hospitality and tourism classes at a university in the southeastern United States. In accordance with previous research, hospitality students in this sample tended to prefer active learning opportunities. Implications, suggestions for teaching and further research, and limitations are presented.
\end{abstract}

\section{INTRODUCTION}

Varied approaches to learning have been observed in general and among students in specific disciplines, including those that study hospitality and tourism (Dale \& McCarthy, 2006; Lashley \& Barron, 2006, Lashley, 1999). Students may indicate that they prefer to learn in particular ways and historically, different learning styles have been proposed, often determined by various learning style inventories developed over the last few decades (e.g. Dunn \& Dunn, 1989; Felder \& Silverman, 1988; Fleming, 200I; Fleming \& Mills, 1992; Gregorc, 1979; Honey \& Mumford, 2000; Kolb, 1984). However, in spite of the work on learning styles and subsequently on the process of assessing the learning styles and then matching these to teaching styles, a number of scholars indicate that there is not enough evidence from research to indicate that students learn better through their own specific learning styles (e.g. Kazan, 2018; Kirschner, 20I7: Newton \& Miah, 20I7; Pashler, McDaniel, Rohrer, \& Bjork, 2008). The focus on learning styles as a means to enhance learning has even been called a "myth" (e.g. Kirschner, 2017; Newton \& Miah, 2017). Given that evidence does not appear to weigh in favor of the use of learning styles, the question arises as to whether or not students' learning preferences matter.

Although learning styles have been disputed by the work of numerous scholars (e.g. Farka, Mazurek, \& Marone, 2016; Newton \& Miah, 2017), it is hard to argue that attention to how students prefer to learn is not important since students make choices about where they wish to learn (in terms of the institutions they choose and the programs they select), about how they study, and about how their needs or desires with regard to learning can best be met. Yet, even though previous studies have focused on documenting students' learning styles, few studies have addressed the need for students to understand their own learning preferences and how those may impact how and what they learn. Knowing more about how students prefer to learn is important in education in all subject areas, including hospitality and tourism, especially as course delivery modes continue to become more varied to include not only face-to-face classes and fully online ones, but also and increasingly a broad range of hybrid courses as well, using a variety of types of technology.

Therefore, through this Scholarship of Teaching and Learning (SoTL) study, the author sought to understand more about how hospitality and tourism students prefer to learn, to have students reflect on their own learning, as recommended by others (e.g. Kaplan, Silver, Lavaque-Manty, \& Meizlish, 20I3), and to consider the implications that these preferences have for instructor-centered and student-centered teaching methods. For even if learning styles are considered a myth by a number of scholars, students' preferences for how they learn may make a difference in terms of what subjects and disciplines they choose to study and ultimately how and what they choose to learn.

\section{BACKGROUND \\ Learning styles}

Learning styles have been defined as "individual differences in learning based on the learner's preference for employing different phases of the learning cycle. Because of our hereditary equipment, our particular life experiences, and the demands of our present environment, we develop a preferred way of choosing among the four learning modes "(Kolb \& Kolb, 2005, p. I94- 195). By the four learning modes, this definition is referring to abstract hypotheses, active testing, concrete experience, and reflective observation (Zull, 2002).

In addition, as noted, different learning styles have been proposed for students in general and several learning style instruments have been developed (e.g. Dunn \& Dunn, 1989; Felder \& Silverman, 1988; Fleming, 2001; Gregorc, 1979; Honey \& Mumford, 2000; Kolb, 1984). Kolb (1984) was instrumental in exploring learning styles and his research focused on how students have preferences for being active learners versus reflective learners and he noted that learning style is not static, but instead it is dynamic and can change. The processing of information in Kolb's (1984) model was from concrete to abstract, which was also the focus of work by Gregorc (1979), while Honey and Mumford (2000) created an inventory directed toward management trainees that has been used to indicate if a person can be classified as an activist, reflector, theorist, or pragmatist.

Other models include the one developed by Felder and Silverman (1988) that considered the intake of information for cognitive processing and has students assess whether they are learners that are sequential-global, active-reflective, verbal-visual, or sensing-intuitive and the VARK model (Fleming \& Mills, 1992; Fleming, 200 I; 20I4; Leite, Svinicki, \& Shi, 20I0), which involves a 
relatively brief instrument that attends to four learning modalities that include visual or graphic $(\mathrm{V})$, auditory $(A)$, writing $(R)$, or kinesthetic $(K)$ learning preferences. As mentioned previously, the strategy behind using various learning style inventories has been to identify a student's learning style and then match the type of instruction with that particular learning style; however, no one model has been found to be suitable for understanding the teaching and learning of all students (Lashley \& Barron, 2006) and the effectiveness of the use of learning styles has been challenged in education in general (e.g. Newton \& Miah, 2017; Kirschner, 20I7) and in hospitality and tourism education (e. g. La Lopa \& Wray, 2015).

\section{Learning styles disputed}

A number of educators do not believe that the congruence between teaching methods and learning preferences necessarily enhances student learning and believe that learning styles, at least as studied, are an illusion (e.g. Grasha, 1990; Kirschner, 2017; Newton \& Miah, 2017; Reiner \& Willingham, 2010; Stellwagen, 200I). Some scholars note that the matching theory, consisting of matching teaching methods with learning styles, does not appear to work effectively (La Lopa \& Wray, 20I5), and others indicate that there is no evidence of the effectiveness of learning styles as a teaching tool (Kirschner, 2017; Newton \& Miah, 2017). Still others insist that, without further rigorous experimental research, there is not substantial evidence to justify their use (Farkas, Mazurek, \& Marone, 2016; Pashler, et al., 2008). Furthermore, some scholars believe that identifying students with a specific learning style may have students themselves believe that they can only do well with a particular method of teaching and may make them become too dependent on that knowledge of their style and thus, confuse the actual learning that can occur with a number of methods as they experience varied life and learning opportunities (e.g. Kirschner, 2017;Grasha, 1990; Kazan, 2018; Murphy, Gray, Straja, \& Bogert, 2004; Pashler, et al., 2008; Stellwagen, 200I).

\section{Learning preferences}

Although there is controversy over and lack of agreement about learning styles, how students learn and how they prefer to learn make a difference in terms of the types of learning activities and assignments that might be optimally used in classrooms in higher education, based on the concepts and skills to be learned (Pashler et al. 2008). The term, learning preferences, is typically viewed as a more encompassing group of characteristics than learning styles, for they usually are also concerned with features that might influence learning, such as the setting, situation, and atmosphere, including where and when students prefer learn (Plass, Chun, \& Mayer, 1998). Interestingly, some scholars (Hawk and Shah, 2007) contend that educators in higher education use a teaching style that combines the ways that they prefer to learn with the methods that they observed to be effective in their own experiences as students in higher education, noting that college and university educators often do not have extensive training in teaching methods. Still, even though the validity of learning styles has come under question, instructors would do well to pay attention to the learning preferences of their students to encourage attendance, maintain student interest, and enhance engagement and therefore, increase opportunities for learning to occur (Hawk \& Shah, 2007). Additionally, as scholars have noted, having students engage in metacognition and self-reflection can help students to understand more about how they learn (Kaplan, Silver, Lavaque-Manty, \& Meizlish, 20I3).

\section{Learning preferences in hospitality and tourism education}

In hospitality and tourism education, some researchers have also found a lack of congruence between learning styles and a student's learning preferences (La Lopa \& Wray, 20I5). In terms of learning preferences, studies have shown that hospitality and tourism students tend to be more active rather than reflective learners (Green \& Sammons, 20I4) and teaching strategies that do not take this into account, particularly for less experienced students, may lead to less than satisfactory learning outcomes (Lashley \& Barron, 2006). Cultural differences may also exist with regard to learning preferences and balanced approaches to learning, such as experiential learning strategies, may be helpful tools (Lashley \& Barron, 2006). For example, in a study conducted two decades ago, Lashley (1999) found that hospitality and tourism students tended to have inclinations toward active learning and a desire for new experiences. Thus, as Barron and Arcodia (2002) noted, hospitality and tourism students shared a preference for group activities that are interesting, challenging, and dynamic. In addition, they observed that hospitality management students appreciated applied activities and they were not so much at ease with theoretical or reflective work (Barron \& Arcodia, 2002). More recently, investigators observed that hospitality and tourism students prefer the use of media (such as movies, films, and videos) and hands-on learning and do not care for group projects, audiotapes, or long lectures (La Lopa \&Wray ,2015).

\section{The purpose of the study}

It has been suggested that instructors create a dialogue with their students about learning so as to address the diversity among students' approaches to learning, communicate effectively, and truly help students acquire knowledge and skills (Fleming, 2012; Montgomery \& Groat, 1998; Newton \& Miah, 2017). Therefore, given that understanding how students prefer to learn can help enhance the teaching and learning environment, this SoTL study, explored what students' views are of learning to help instructors create better learning opportunities for students. Specially, this SoTL study sought to answer the following question: How do hospitality management students prefer to learn?

\section{METHODS}

This study was defined as a Scholarship of Teaching and Learning (SoTL) study and as scholars note, definitions of SoTL work vary by local context (Simmons \& Marquis, 2017). However, as Simmons and Marquis (2017) observed, irrespective of the countless viewpoints, disciplines, and educational contexts, the spirit of SoTL was well stated by Poole and Simmons (2013) as being to "improve student learning and enhance educational quality" (p. I I8). With that in mind, this SoTL study focused on exploring students' learning preferences, to aid teaching and learning in the hospitality and tourism classroom, by applying qualitative methods to determine students' learning preferences.

For this SoTL study, undergraduate hospitality management students were asked to reflect on their own learning preferences. Perceptions of students' learning preferences were gathered from undergraduate hospitality management students in six face- 
to-face classes in their major area of study at a public university in the southeastern United States (U.S.) during the 2017-2018 academic year. Their answers were gathered anonymously so that the students would feel free to express their thoughts. Students were able to voluntarily complete the reflection and it did not influence their grade in a course.

To analyze the reflective narratives written by students, content analysis was applied (Berg, 2004; Malterud, 20I2). In this study, thematic analysis was used, based upon the method addressed by Braun and Clark (2006). The author and two graduate students coded the data independently. In the first step, the reflections were read as a whole and then during the second step, the reflections were read again and they were coded by placing labels on intriguing and frequently mentioned text. In the third step, the codes were reviewed for themes and in the next step, the themes were defined and named (Braun \& Clarke, 2006). The coders compared the themes that they derived from the data as a form of cross-validation of the final elucidation of the reflections, as suggested by scholars in the area of content analysis (Berg, 2004; Malterud, 2012; Neuendorf, 2002).

These methods were chosen for use in this study for several reasons. One was that they allowed students to fully express their views and the second was that students' voices can clearly communicate what they mean by their preferences more completely than via a score on a scale. Third, there are numerous learning scales available, but these would not garner the introspection that reflections provide and this method allowed the instructor to gain information about students immediately in the students' own words. Finally, as noted above, in terms of learning style inventories, there is not necessarily enough evidence in favor of one instrument over another (Newman \& Miah, 2017; Pashler, et al., 2008).

Based on the literature on learning preferences in general and related to hospitality and tourism (e.g. Barron \& Arcodia, 2002; La Lopa \& Wray, 20I5; Lashley, 1999; Pashler, et al., (2008; Stevens, Kitterlin, \& Tanner, 20I2) and considering metacognition and reflection as suggested by Kaplan, et al., (20l3), students were asked via an online survey link to reflect in writing on the following topics in paragraph form: how they learn best with regard to their classes; what makes it easy to learn in a class versus what makes it difficult to learn; how they studied for a recent examination; when have instructors used methods that connect to their learning preferences, providing an example of how this occurred.

\section{RESULTS}

The survey link was sent to 196 undergraduate hospitality management students and 149 completed the survey. The sample was composed of freshman $(n=59)$, sophomores $(n=48)$, and juniors (42). Of those students, 106 indicated that they were female (7I.I\%) and 43 stated that they were male (28.9\%), while II 8 (79.2\%) answered that they were Caucasian, 17 (II.4\%) stated that they were African American, 5 (3.3\%) indicated that they were Hispanic, and 8 (5.3\%) indicated that they were of other backgrounds. The sample was representative of the students enrolled in the hospitality program at the university.

All of the 149 respondents began their first reflective paragraph with a comment about something an instructor does in a class. The majority of answers focused on teaching methods. For example, the most common answer was that the students believed that they learned best in classes where the instructor does not just lecture $(n=56)$. A short, but explanatory example of part of such an answer was the following "... when the class is interactive and not just a lecture." A number of students noted that they learned best when the instructor explains things carefully $(n=34)$, when he or she uses some kind of visual aids $(n=23)$, and when he or she has students complete hands-on activities $(n=2 I)$. Other answers focused on statements about the instructor's behavior and included the following items: being enthusiastic $(n=14)$, engaging $(n=14)$, involved $(n=11)$, interactive $(n=11)$, caring $(n=9)$, entertaining $(n=6)$, nice $(n=6)$, willing to help $(n=6)$, and passionate $(n=5)$.

Interestingly, students also mentioned how other students helped them to learn in their classes, noting that the students helped them to learn when they asked questions $(n=5 I)$. For example, one respondent wrote the following about other students helping him or her to learn such that they "help me understand something better than the teacher." Another common answer dealt with student conduct in the classroom and focused on behaviors such as being respectful, quiet, and paying attention $(n=40)$.An excerpt from one student's answer regarding this topic included the following: "they are quiet unless we are doing an interactive activity." Another student wrote that other students "are quiet while you are teaching, but active in work."

A number of students focused on what makes a class environment one in which they would be likely to participate, focusing on their own attitudes and behaviors, with a common answer relating to their own interest in the subject or class $(n=47)$ or their own comfort level with the material $(n=33)$ or with the class environment $(n=26)$. Example excerpts from students' responses included the following: "the topic is interesting and the class is interactive," "I am knowledgeable about the subject," and "I participate in classes when they are smaller or others are participating as well."

Students provided a variety of answers about what makes it easy or difficult to learn in a class. They identified having an interactive, enthusiastic, kind instructor $(n=55)$ and including handson activities $(n=42)$ as making a class an easy place to learn. Typical responses included the following: "a teacher passionate about the subject who really wants students to learn," "when I am interested in the topic we're discussing," "good communication from the professor," and "organized assignments and class schedules that are available." When identifying something that makes it difficult to learn in a class, students focused on finding it challenging to learn when it is only a lecture class $(n=44)$ and when it is boring $(n=34)$. They also mentioned that it was hard to learn when an instructor was unprepared $(n=18)$ and goes off on a tangent $(n=26)$.

Assignments were mentioned by almost all of the students and as far as assignments that they preferred, a large number of students identified group work and projects as their favorites $(n=54)$, while a few students preferred working on assignments alone $(n=7)$. Other assignments that they liked include those that they could complete online $(n=24)$ and those involving creativity $(n=20)$. Some students indicated that they preferred assignments that did not require writing $(n=30)$ or a lot of reading $(n=18)$. A number of students indicated that they learned by doing handson activities $(n=55)$, engaging in group interaction $(n=43)$, and participating in visual activities $(n=30)$. Interestingly, these results were not completely congruent with previous findings that indi- 
cated that students did not like group work and particularly liked to learn via media sources, although this study did find that students enjoyed learning through hands-on activities and did not care for lectures (La Lopa \&Wray, 2015).

Examples of representative excerpts from the students' responses about how they learned best included the following:

I learn best when the professor makes the classes about each individual student and how they'll apply the material to their everyday lives, both personally and professionally. I want to learn new things and be exposed to new ideas in all of my classes. I don't like to be bound by an old-fashioned textbook. Don't get me wrong, I know that textbooks can contain valuable information and help me to learn important concepts, but I learn best when that textbook material is made real and when we discuss it and use it in group projects that are meaningful and not just completed to check off a box. I like to have new experiences in my classes and to be engaged with the material and the assignments.

I learn best through hands-on activities and not through straight lecture classes where a teacher talks about the chapters and then just gives us tests or a midterm and a final exam. I learn best when instructors don't just tell me what to do and what to know, but instead show me and let me try to do it myself through trial and error. Also, I learn best in classes that involve me and my fellow students in group projects about real topics that matter and when I have some choice about the topic or at least the way to go about completing the project for the class. Group projects can be really difficult, but I know that I learn about the subject and about myself through doing them.

I learn best through when I process the material with my peers and discuss the content materials or do problems with other students. I get a start on learning through the lecture, but I really do learn best when I talk things over with my fellow students and work on assignments and/or projects together.

I don't like projects, but I have to admit that I learn best through them, especially when they involve problem-based learning. I think it is really good when we have opportunities to work together in groups on real-world projects that have a variety of outcomes and not just one answer. I feel that that is genuine learning for the real world.

The question that asked the students to reflect upon the methods or activities that they engaged in to study for their most recent examination in hospitality and tourism also received a variety of answers. Activities mentioned included reading $(n=92)$ and rereading the text $(n=79)$, reviewing notes $(n=69)$ and PowerPoint slides $(n=94)$, and talking over the content material with other students $(n=48)$. Interestingly, quite a few students noted that they had difficulty thinking about this question and had not ever thought about how they studied $(n=49)$. A representative comment from this group included the following:

I have never thought about this before. I guess I don't really know what I do to study. I am going to have to think about this in the future because my mind is kind of a blur as to what I did for the last test. Sure, I read the textbook and other material, but I am not sure of the process I go through to make sure I am ready for an exam. This is something I need to think about more carefully.
As far as students' views as to whether or not instructors used teaching methods that were congruent with their learning preferences, the answers were mixed. Approximately half of the students indicated that instructors addressed their learning preferences in some way in their classes $(n=74)$ while the other half indicated that this was not the case in their courses $(n=75)$. Affirmative examples included the following:

I have a couple of professors that do this all the time. They offer us different types of assignments and even choices in terms of the types of projects. In one class I could make a video instead of writing a paper and this was great because I like to do hands-on, visual kinds of things.

One professor mixes things up a lot. One assignment might involve watching a you tube video and making comments on it while the next assignment might be to interview a classmate and record the interview and another assignment might be to evaluate a research study. It's pretty cool how you get to do a variety of assignments all in one class. It keeps the class interesting and makes me want to learn

Examples of instructor behaviors that did not address different learning preferences included the following.

I have to say that my classes are pretty much all the same. The teacher lectures, we take multiple choice tests and we do some kind of paper/project. It's actually pretty boring and sometimes I just have to force myself to stay engaged in my classes because they are the same old same old.

My classes are all taught by lectures with PowerPoint slides. Sometimes we might have a discussion, but most of the time there is just a lecture and then a test over the lecture and textbook. I am not thinking that learning preferences have been an idea behind these classes.

\section{DISCUSSION AND IMPLICATIONS}

Not surprisingly, in accordance with earlier research findings, hospitality students in this sample tended to prefer active learning opportunities (e.g. Barron \& Arcodia, 2002; Green \& Sammons, 20I4). They shared that they did not like to learn in a passive way, they did not care for lectures, they preferred to work in groups, and they wanted to use their creativity.

Interestingly, the students placed a heavy emphasis on what the instructor does in a class and perhaps that has to do with the teacher-centered ways that higher education has often been approached historically or because of the wording of the questions, or perhaps it related to the fact that the students were primarily young undergraduate students, or perhaps it was due to all three reasons. While there are benefits to both teacher-centered and student-centered approaches to learning, student or learner-centered methods focus on the learner instead of the teacher and attend not only to the delivery of content that is so prevalent in college classrooms, but on what students can do (Weimer, 2002). Focusing on what students do may also lead to changes in an instructor's behaviors, so perhaps focusing on the student truly makes sense. Although critics have debunked learning styles by stating that there is no evidence that they are useful, it would seem, as Fleming (20I2) the author of the VARK learning inventory indicated, that it is indeed helpful to an individual student to understand more about how he or she learns. In addition, an instructor might do well to help his or her students reflect on 
their own learning preferences so as to improve their learning. For example, some people prefer to study alone in a quiet place while others might enjoy listening to music and studying with or near others and knowing this about one's self and one's students could be probably be helpful (Fleming, 20I2).

Some ways to use teaching methods to address how students indicate that they like to learn, so as to enhance learning in face-to-face, online, or hybrid classes that emerged from this study, include revamping the lecture method, using peer instruction techniques, implementing problem-based learning into one's course, incorporating hands-on activities, and considering instructor behaviors (see Figure I). To augment this process of selecting teaching strategies, even though critics debunk learning style evidence related to learning in research studies, some recommend using learning style inventories as tools (Farkas, Mazurek, \& Marone, 2016; Hawk \& Shah, 2007; Kazan, 20 I8;)

Furthermore, although student learning preferences may matter, many factors play into how a class or a particular lesson

\begin{tabular}{|c|c|}
\hline \multicolumn{2}{|c|}{ Figure I:Teaching Tactics for Learning-Centered, Student-Centered Classes } \\
\hline Tactic & Description \\
\hline $\begin{array}{l}\text { Revamped } \\
\text { Lectures }\end{array}$ & $\begin{array}{l}\text { Improve a lecture by making it more interactive. Exam- } \\
\text { ples include integrating technology into the lecture (e.g. } \\
\text { Calma,Webster, Petry, Pesina, 20I4) and using the Think- } \\
\text { Pair-Share (TPS) activity. The TPS activity is conducted in } \\
\text { the following manner: } \\
T: \text { (Think) Instructors start by asking a particular ques- } \\
\text { tion about the course content. Students "think" about } \\
\text { what they know or have learned about the subject. } \\
P: \text { (Pair) Each student is then paired with another student } \\
\text { or a small group to discuss the topic. } \\
S: \text { (Share) Students share their thinking with their part- } \\
\text { ner(s) and then with the entire class through an instruc- } \\
\text { tor-led discussion. (e.g. Gunter, Estes, \& Schwab, I999; } \\
\text { Huang, 2002; Lyman, I98I;Millis \& Cottell, I998) }\end{array}$ \\
\hline $\begin{array}{l}\text { Peer } \\
\text { instruction }\end{array}$ & $\begin{array}{l}\text { Peers help teach each other. The instructor expects stu- } \\
\text { dents to be familiar with the information prior to class } \\
\text { so that they can spend class time attempting to under- } \\
\text { stand the meaning of the information. Students use a } \\
\text { web-based tool to submit questions about the reading } \\
\text { material before class begins and the instructor creates } \\
\text { a set of multiple-choice questions based on their ques- } \\
\text { tions. In class, the instructor gives a brief introduction } \\
\text { and students answer the first question and then talk over } \\
\text { the item with the student next to them and then the stu- } \\
\text { dents answer the question again. Researchers have found } \\
\text { that their students do much better after speaking with } \\
\text { their classmates (e.g. Crouch \& Mazur, 200I) }\end{array}$ \\
\hline $\begin{array}{l}\text { Problem-based } \\
\text { learning }\end{array}$ & $\begin{array}{l}\text { Experiential learning through solving problems in groups, } \\
\text { often called problem-based learning (PBL), can provide } \\
\text { students with meaningful learning opportunities. Stu- } \\
\text { dents work collaboratively in groups in PBL, using self-di- } \\
\text { rected learning approaches to solve complex problems } \\
\text { where no one correct answer is sought and the instruc- } \\
\text { tor acts as a facilitator (e.g. Hmelo-Silver, 2004). }\end{array}$ \\
\hline $\begin{array}{l}\text { Hands-on } \\
\text { activities }\end{array}$ & $\begin{array}{l}\text { Incorporate experiential learning activities, active learn- } \\
\text { ing activities, service learning opportunities, authen- } \\
\text { tic projects, and community based projects, and apply } \\
\text { concepts to practice (e.g. Huang, 2002; Yale Center for } \\
\text { Teaching and Learning, 20I7) }\end{array}$ \\
\hline $\begin{array}{l}\text { Instructor } \\
\text { behaviors }\end{array}$ & $\begin{array}{l}\text { Enhance one's own strengths and be true to one 's self. } \\
\text { However, consider being a strategist to teach effectively, } \\
\text { given the context by considering constructive communi- } \\
\text { cation, subject competence, reflection on practice, and } \\
\text { engaging in action research or SoTL to improve learning } \\
\text { and teaching (e.g. Moore, 2000). }\end{array}$ \\
\hline
\end{tabular}

is taught, including such factors as the specific discipline, content material and skills to be taught, class size, classroom configuration, classroom environment (such as lighting, and temperature), instructor personality, classroom dynamic between an instructor and his or her students (Hara, 2009), and class format in terms of a face-to-face class, a blended class that is a hybrid of face-to-face and online delivery methods, and a fully online course.

There is merit to understanding how students wish to learn so that an instructor can expand his or her teaching methods to be more inclusive, to aid student learning, and to make teaching more rewarding. For example, a lecture-driven lesson can easily be augmented by small group discussions and simple interactive methods, thereby increasing opportunities to reach students with a variety of learning preferences. Additionally, there is wisdom in helping students to increase their ability to learn in a variety of ways. Students entering careers in the hospitality industry will, in all likelihood, need to be able to demonstrate a variety of skills that have been identified as desirable by the industry, such as the capacities to build connections, multitask, pay attention to detail, use technology and language effectively, and exhibit flexibility (Hcareers, 20I5).

In addition, although students may not favor a commonly used teaching method such as the lecture and therefore, may choose not to attend class, educators would do well to look beyond the thought that not attending class is a sign of disrespect and instead try to understand a bit more about how students like to learn (Murphy, et al., 2004). Furthermore, as Murphy and his colleagues noted, "The simple gesture of an instructor asking a student "How would you like me to teach you?" may lead to a meaningful discussion of new ways to create a deeper level of learning (Murphy, et al., 2004, p. 865).

Not surprisingly, the act of writing itself is seen as a way of learning (Jasper, 2005) and as a means to think more deeply about one's own beliefs (Crabtree, 2008) and increase one's self-awareness and introspection (Hattan \& Smith, 1995; Scanlan, Care, \& Udod, 2002). Conceivably, both instructors and students can benefit from becoming more self-reflective about learning and also communicate better with each other about learning strategies that can and do work. Further meaningful dialogue between students and instructors is needed, and not in the form of complaint sessions, to better understand how students can learn effectively and instructors can teach effectively. Perhaps as noted, it is useful for instructors and students in all different kinds of learning environnments and courses to have open, frank conversations about how the students prefer to learn and how they think that they learn best. Asking students how they prefer to learn and even using simple activities such as a short list of questions about how they like to learn, including items such as how they learn best and what assignments they prefer (e.g. Goza, 1993; Weimer, 2013) could help to create better learning environments for students and their instructors.

\section{Limitations and further research}

This SoTL study has several limitations. It used a case study approach and the study's sample came from one university, the data were gathered from students in face-to-face courses, and the methodology was a simple, reflective, qualitative one. Differences between learning preferences based on student characteristics such as cultural background, nationality, gender, and age were not attained, nor were any variations based on course modal- 
ity (in-person, online, or hybrid), students' career plans, such as whether there might be differences between those focusing on the lodging, food and beverage, or meetings and events sector of the industry, determined. Further in-depth investigations, perhaps using more quantitative approaches, are needed to learn more about student learning preferences and how these interact with teaching methods to provide the most effective hospitality and tourism education possible.

\section{REFERENCES}

Barron, P. E., \& Arcodia, C. (2002). Linking learning style preferences and ethnicity: International students studying hospitality and tourism management in Australia. Journal of Hospitality, Leisure, Sport and Tourism Education, I (2), I5-27.

Berg, B. L. (2004). Qualitative research methods for the social sciences (5th ed.). Boston, MA: Pearson/Allyn and Bacon.

Calma, A., Webster, B., Petry, S., \& Pesina, J. (20I4). Improving the quality of student experiences in large lectures using quick polls, Australian Journal of Adult Learning, 54 (I) I| 4 - I 36.

Crouch, C. H., \& Mazur, E. (200I). Peer instruction: Ten years of experience and results. American Journal of Physics, 69 (I), 970-977. http://doi: I0.1 I I9/1.1374249

Dale, C., \& McCarthy, P. (2006). I like your style:The learning approaches of leisure, tourism and hospitality students studying generic modules. Journal of Hospitality, Leisure, Sport and Tourism Education, 5(2), 48-58.

Dunn, R., \& Dunn, K. ( 1989). Learning style inventory. Lawrence, KS: Price Systems.

Farkas, G. J., Mazurek, E., \& Marone, J. R. (20I6). Learning style versus time spent studying and career choice:Which is associated with success in a combined undergraduate anatomy and physiology course? Anatomical Sciences Education, 9(2), | 2 I-I3|, http://doi.I0.1002/ase.I563

Felder, R. M., \& Silverman, L. K. (1988). Learning styles and teaching styles in engineering education. Engineering Education, 78(7), 674-68I.

Fleming, N. D. (200I).Teaching and learning styles:VARK strategies. Christchurch, New Zealand: N.D. Fleming.

Fleming, N. (20I2). The case against learning styles. Vark-Learn. Retrieved from http://www.vark-learn.com/wp-content/uploads/2014/08/The-Case-Against-Learning-Styles.pdf

Fleming, Neil D., (20I4), "VARK: A Guide to Learning Styles", Vark-Learn. Retrieved from http://www.vark-learn.com

Fleming, N. D., \&Mills, C.(1992), Not another inventory, rather a catalyst for reflection, To Improve the Academy, I I (I), I37-| 55.

Goza, B. K. (1993). Graffiti needs assessment: Involving students in the first class session. Journal of Management Education, I7(I), 99-106.

Grasha,T. (1990). The naturalistic approach to learning styles. College Teaching, 38(3), I06-14. 20.

Green,A., \& Sammons, G., (20I4). Student learning styles:Assessing active learning in the hospitality learners model. Journal of Hospitality \& Tourism Education, 26(I), 29-38.

Gregorc, A. F. (1979). Learning/teaching styles: Their nature and effects. NASSP Monograph (October/November), 19-26.

Gunter, M.A., Estes, T. H., \& Schwab, J. H. (1999). Instruction:A models approach, 3rd edition. Boston:Allyn \& Bacon.

Hara, B. (2009). Teacher-centered vs. student-centered pedagogy, September 18. The Chronicle of Higher Education. Retrieved from http://www.chronicle.com/blogs/profhacker/teacher-centered-vs-student-centered-pedagogy/227/4

Hawk, T. F., \& Shah,A.J. (2007). Using learning style instruments to enhance student learning. Decision Sciences Journal of Innovative Education, 5(I), I-I9.

Hcareers (20I5). 5 job skills hospitality employers want to see, Sept 5. Retrieved from https://www.hcareers.com/article/ advice-from-employers/5-job-skills-hospitality-employers-want-to-see

Hmelo-Silver, C. E. (2004). Problem-based learning: What and how do students learn? Educational Psychology Review, I6(3), 235-266.

Honey, P. \& Mumford, A. (2000) The Learning Styles Questionnaire: 80 Item Version. Maidenhead: Peter Honey Publications.

Huang, H. (2002). Toward constructivism for adult learners in online learning environments, British Journal of Educational Technology, 33 (I), 27-37.

Kaplan, M., Silver, N., Lavaque-Manty, D., and Meizlish, D.(20I3). In, Kaplan, M., Silver, N., Lavaque-Manty, D., and Meizlish, D., ( eds.), p.i-xi). Using reflection and metacognition to improve student learning. Sterling,VA: Stylus.

Kazan, O. (2018, April II). The myth of "learning styles." The Atlantic. Retrieved from https://www.theatlantic.com/science/ archive/2018/04/the-myth-of-learning-styles/557687/

Kirschner, PA. (2017). Stop propagating the learning styles myth. Computers \& Education, I06(I), I66-I7I.

Kolb, D. (1984).Experiential learning: Experience as the source of learning and development. Englewood Cliffs, NJ: Prentice-Hall.

Kolb, A.Y., \& Kolb, D.A., (2005). Learning styles and learning spaces: Enhancing experiential learning in higher education. Academy of Management Learning \& Education, 4 (2), 193-2 12.

La Lopa,J., \&Wray, M. (20I5). Debunking the matching hypothesis of learning style theorists in hospitality education. Journal of Hospitality \& Tourism Education, 27 (I), I20-128.

Lashley, C., \& Barron, P. (2006). The learning style preferences of hospitality and tourism students: Observations from an international and cross-cultural study. International Journal of Hospitality Management, 25(4), 552-569.

Lashley, C. (1999). On making silk purses: Developing reflective practitioners in hospitality management education. International Journal of Contemporary Hospitality Management, I I (4), I80-185.

Leite, W. L., Svinicki, M., \& Shi, Y. (20l0). Attempted validation of the scores of theVARK: Learning styles inventory with multitrait-multi-methods confirmatory factor analysis models. Educational and Psychological Measurement, 70(2), 323-339.

Lyman, F. (198I). The responsive classroom discussion. In Anderson, A. S. (Ed.), Mainstreaming Digest. College Park, MD: University of Maryland College of Education.

Millis, B. J., \& Cottell, P. G., Jr. (1998). Cooperative learning for higher education faculty, American Council on Education, Series on Higher Education. The Oryx Press: Phoenix, AZ. Mazur, E. (1997). Peer instruction: A user's manual. Upper Saddle River, N.J.: Prentice Hall

Montgomery, S.M., Groat, L. N. (1998). Student learning styles and their implications for teaching. Occasional paper \#I0. Ann Arbor: Center for Research on Learning and Teaching, University of Michigan. Retrieved from https://crlte.engin.umich.edu/ wp-content/uploads/sites/7/2013/06/occ_paper I 0.pdf

Moore, A. (2000). Teaching and learning: Pedagogy, curriculum and 
culture. London: Routledge Falmer.

Murphy, R. J., Gray, S. A., Straja, S. R., \& Bogert, M. C. (2004). Student learning preferences and teaching implications. Journal of Dental Education, 68(8), 859-866.

Neuendorf, K.A. (2002). The content analysis guidebook. Thousand Oaks, CA: Sage Publications.

Newton, P.M., \& Miah, M. (20I7, March 27). Evidence-based higher education-is the learning styles "myth" important? Frontiers in Psychology Retrieved from https://www.frontiersin.org/articles/ I 0.3389/fpsyg.20 17.00444/full

Pashler, H., McDaniel, M., Rohrer, D., \& Bjork, R. (2008). Learning styles concepts and evidence. Psychological science in the public interest, 9(3), I05-II9.

Plass, J.L., Chun, D. M., \& Mayer, R. E. (1998). Supporting visual and verbal learning preferences in a second-language multimedia learning environment, Journal of Educational Psychology, $90(1), 25-36$.

Poole, G., \& Simmons, N. (20I3). The contributions of the scholarship of teaching and learn-

ing to quality enhancement in Canada. In G. Gordon, \& R. Land (Eds.), Quality enhancement in higher education: International perspectives (pp. I I8-128). London: Routledge.

Reiner, C., \& Willingham, D. (2010). The myth of learning styles. Change, 42(5), 32-35.
Simmons, N., \& Marquis, E. (2017). Defining the scholarship of teaching and learning, The Canadian Journal for the Scholarship of Teaching and Learning, 8(2) I-3. https://doi.org//0.5206/ cjsotl-rcacea.2017.2.2

Stellwagen J., (200I). A challenge to the learning style advocates. Clearing House, 74(5), 265-9.

Stevens, D. P., Kitterlin, M., \& Tanner, J. R. (2012). Assessing the impact of learning styles for hospitality students. Consortium Journal of Hospitality \& Tourism. 17 (I), I-23.

Weimer, M. (2013, January 9). First day of class activities that create a climate for learning. Faculty Focus. Retrieved from http://www.facultyfocus.com/articles/teaching-professor-blog/first-day-of-class-activities-that-create-a-climatefor-learning/

Weimer, M. (2002). Learner-centered teaching: Five key changes to practice. San Francisco: Jossey-Bass/John Wiley \& Sons.

Yale Center for Teaching and Learning (2017). Active and experiential learning. http://ctl.yale.edu/teaching/teaching-how/ chapter-4-increasing-critical-thinking-and-motivation/active-and-experiential-learning

Zull, J. E. (2002). The art of changing the brain: Enriching teaching by exploring the biology of learning. Sterling,VA: Stylus. 